\title{
Comparative Analysis of Heavy Metals and Useful Components of Marine Resources with Potential Healing Properties
}

Byung-Loc Kim, Yun-Hee Choi, Hak-Sung Lee, Yong-Gi Jeong*

Center of Natural Resources Research, Jeonnam Bioindustry Foundation, Jangheung-gun, Jeollanam-do, Korea

\author{
*Corresponding author: Yong-Gi Jeong, \\ Center of Natural Resources Research, \\ Jeonnam Bioindustry Foundation, 288 \\ Woodland-gil, Anyang-myeon, Jangheung- \\ gun, Jeollanam-do 59338, Korea \\ Tel.: +82618602630 \\ Fax: +82 618647105 \\ Email: go6115@nate.com
}

Received August 30, 2019

Revised October 22, 2019

Accepted November 4, 2019

Published December 30, 2019

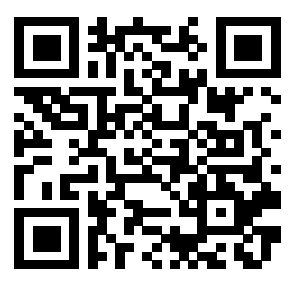

\begin{abstract}
Purpose: Because of their unique biological and technological properties, the potential of marine resources in cosmetic applications is well recognized. In this study, we performed a comparative analysis to investigate the safety and quality of various potential marine resources for healing and clinical applications were collected from four regions in South Korea: Uljin, Goseong, Wando, and Taean. Methods: A total of seven types of potential marine resources for healing (peat, mud, sea sand, seaweed, black pine, saline ground water, and sea water) and nine types of marine resources for clinical applications (namely, peat, mud, sea mustard, laver, black pine, sea salt, oyster, oyster boiled water, and saline ground water). Following pre-treatment of samples, we used inductively coupled plasma optical emission spectrometry (ICP-OES) to detect, chemically analyze, and quantify the concentrations of seven heavy metals and useful components (lead, arsenic, cadmium, potassium, sodium, calcium, and magnesium) in the marine samples.. Furthermore, a mercury analyzer was employed to detect and evaluate the concentration of mercury, a common ingredient used in skin lightening soaps and creams. Results: Results of the heavy metal analysis confirmed that marine resources for healing and for clinical applications conform to all safety standards of cosmetics at the Ministry of Food and Drug Safety. Hence, they are suitable for cosmetic applications. However, the lead content of arsenic and peat resources in seaweed was found to be high. In addition, the results of this quality comparison analysis were found to be similar to the control experiments, despite the fact that minor differences were identified between each resource. More specifically, the lead content in peat was increased, whereas the potassium content was decreased. Conclusion: In this study, the comparative analysis of heavy metals and other useful components from four local marine healing resources demonstrated that these resources are both safe and suitable for healing applications. In the future, it is expected that marine resources for healing will be utilized throughout the marine industry through more continuous and systematic research, management and supervision of industries, universities, research institutes, and government policies.
\end{abstract}

Keywords: Safety, Heavy metals, Useful components, Cosmetics, Marine healing resources

\section{Introduction}

해양치유는 바다의 자연 및 환경 자원을 활용하여 질병의 예방과 건강의 증진을 가져다 주는 활동을 말한다. 해양치유
에 활용될 수 있는 자원으로는 해풍과 해안의 햇볕, 경관, 해 수의 심층수, 표층수, 염지하수, 해양생물, 모래, 머드, 소금, 피트 등 그 종류가 다양하다(Lee et al., 2019). 우리나라는 삼면이 바다인 풍부한 해양치유자원을 활용할 수 있는 좋은 
여건을 갖추고 있다. 이러한 해양치유자원은 인체구조의 구 성성분으로 다양한 생리적 기능을 수행하는 필수영양소인 미 네랄, 생리활성물질 등 유용성분을 함유하고 있지만, 때로는 대기, 토양 및 농산물 등에 직·간접적인 오염원으로 인한 중 금속 등이 포함되어질 수 있다(Jang et al., 2002; Kim \& Ahn, 2012; Lee et al., 2008).

오래전부터 핀란드, 러시아, 독일, 폴란드 등 유럽에서는 해양자원을 활용한 연구를 통해 류마티스, 관절염, 요통, 오 십견 등과 같은 다양한 치유분야에 활용해 오고 있다. 반면 우리나라의 경우, 해수, 염지하수 등이 식수로 활용되거나, 해사, 해송, 갯벌 등이 자연 그대로의 해양 경관으로 활용되 고 있으며, 일부 머드, 피트, 소금 등이 화장품 원료로 상품
화된 사례가 있기는 하지만 해양치유를 전문으로 활용된 예는 부족한 실정이다.

본 연구 소재인 해양치유자원은 경북 울진, 경남 고성, 전 남 완도, 충남 태안 등 4 개 지역의 특산자원인 피트, 머드, 해 사, 해조류, 해송, 소금, 굴, 굴자숙수, 염지하수, 해수 등 총 10 종의 다양한 해양치유자원을 대상으로 연구를 수행하였다. 해양치유자원으로 활용되기 위해서는 우선 해양치유 가능자 원의 안전성 여부와 활용가치를 판단하고, 이를 인체에 적용 할 수 있도록 임상적용 해양치유자원으로 효능을 규명하는 것 이 선행되어야 한다. 이에 해양치유 가능자원은 확보 가능한 자원 발굴지역을 대상으로 연구를 수행 하였으며, 임상적용 해양치유자원은 지역의 잠재력이 있는 특화된 자원을 위주로

Table 1. (A) Samples collected with potential marine healing properties and (B) with potential marine healing properties for clinical applications

(A)

\begin{tabular}{|c|c|}
\hline Sample name & GPS \\
\hline $\mathrm{P}-1(\mathrm{~T})$ & N36 4 47'50.9"E12609'16.9" \\
\hline $\mathrm{P}-2(\mathrm{~T})$ & N36 $46^{\circ} 53.8^{\prime \prime E} 126^{\circ} 08^{\prime} 58.2^{\prime \prime}$ \\
\hline$M(G)$ & 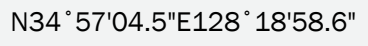 \\
\hline$M(W)$ & N34 ²4'01.9"E12640'16.1" \\
\hline$M-1(T)$ & N36 ${ }^{\circ} 44^{\prime} 50.7^{\prime \prime E} 126^{\circ} 11^{\prime} 06.2^{\prime \prime}$ \\
\hline $\mathrm{M}-2(\mathrm{~T})$ & N36 ㄴ3'49.8"E126¹6'15.3" \\
\hline $\mathrm{Ss}(U)$ & N36 4'35.2"E129 ²8'14.6" \\
\hline $\mathrm{Ss}(\mathrm{G})$ & N34 $55^{\circ} 26.0^{\prime \prime E} 128^{\circ} 13^{\prime} 19.4^{\prime \prime}$ \\
\hline $\mathrm{Ss}(\mathrm{W})$ & N34 19'37.2"E12649'08.6" \\
\hline Ss-1(T) & N36 $38^{\prime} 44.5^{\prime \prime E} 126^{\circ} 17^{\prime} 45.9^{\prime \prime}$ \\
\hline Ss-2(T) & N36 ㄴ 47'19.4"E126 08'32.1" \\
\hline Ss-3(T) & N36 47 '28.6"E12608'47.4" \\
\hline S-1(St)(W) & N34 ¹9'37.2"E12649'08.6" \\
\hline S-2(Sm)(W) & N34 19'37.2"E126 49'08.6" \\
\hline$S-3(H f)(W)$ & N34¹9'37.2"E126 49'08.6" \\
\hline$S-4(S f)(W)$ & N34 19'37.2"E12649'08.6" \\
\hline $\mathrm{Bp}(\mathrm{U})$ & N36 ㄴ 44'35.2"E129 ²8'14.6" \\
\hline $\mathrm{Bp}(\mathrm{G})$ & N34 55'26.0"E128 '13'19.4" \\
\hline $\mathrm{Bp}(\mathrm{W})$ & 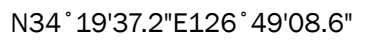 \\
\hline $\mathrm{Bp}(\mathrm{T})$ & N36 $38^{\circ} 44.5^{\prime \prime E} 126^{\circ} 17^{\prime} 45.9^{\prime \prime}$ \\
\hline Sgw-1(U) & N37 04'26.0"E129 24'29.8" \\
\hline Sgw-2(U) & 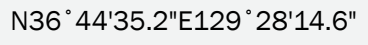 \\
\hline $\mathrm{Sw}(U)$ & N36 ㄴ 44'35.2"E129 ²8'14.6" \\
\hline $\mathrm{Sw}(\mathrm{G})$ & N34 55'26.0"E128 '13'19.4" \\
\hline $\mathrm{Sw}(\mathrm{W})$ & N34 19'37.2"E126 49'08.6" \\
\hline$S w-1(T)$ & N36 $38^{\prime} 44.5^{\prime \prime E} 126^{\circ} 17^{\prime} 45.9^{\prime \prime}$ \\
\hline SW-2(T) & N36 ㄴ 47'19.4"E12608'32.1" \\
\hline
\end{tabular}

(B)

\begin{tabular}{|c|c|}
\hline Sample name & GPS \\
\hline $\mathrm{P}-1(\mathrm{~T})$ & N36 ㄴ 47'50.6"E126 09'17.0" \\
\hline $\mathrm{P}-2(\mathrm{~T})$ & N36 $47^{\prime} 53.5^{\prime \prime E} 126^{\circ} 08^{\prime} 57.5^{\prime \prime}$ \\
\hline$M-3(T)$ & N36 $44^{\prime} 20.4^{\prime \prime E} 126^{\circ} 12^{\prime} 32.6^{\prime \prime}$ \\
\hline $\mathrm{M}-4(\mathrm{~T})$ & N36 $43^{\prime} 19.7^{\prime \prime E} 126^{\circ} 13^{\prime} 21.5^{\prime \prime}$ \\
\hline$M-5(T)$ & N36 $43^{\prime} 50.2^{\prime \prime E} 126^{\circ} 16^{\prime} 34.5^{\prime \prime}$ \\
\hline S-5(Sm)(W) & N34 ${ }^{\circ} 25^{\prime} 73.9^{\prime \prime} \mathrm{E} 127^{\circ} 01^{\prime} 58.6^{\prime \prime}$ \\
\hline S-6(Sm)(W) & N34 ${ }^{\circ} 27^{\prime} 50.0^{\prime \prime E} 127^{\circ} 00^{\prime} 70.6^{\prime \prime}$ \\
\hline S-7(Sm)(W) & N34 ²7'71.4"E127º2'87.8" \\
\hline $\mathrm{S}-8(\mathrm{~L})(\mathrm{W})$ & N34 ² $21^{\prime} 14.3^{\prime \prime E} 126^{\circ} 37^{\prime} 96.6^{\prime \prime}$ \\
\hline S-9(L)(W) & N34 ํ19'22.4"E126 37'80.1" \\
\hline S-10(L)(W) & N34 ${ }^{\circ} 18^{\prime} 06.6^{\prime \prime E} 126^{\circ} 39^{\prime} 30.0^{\prime \prime}$ \\
\hline $\mathrm{Bp}(\mathrm{U})$ & N36 $44^{\prime} 37.4^{\prime \prime E} 129^{\circ} 28^{\prime} 09.0^{\prime \prime}$ \\
\hline Bp-1(U) & N36 $75^{\prime} 24.2^{\prime \prime E} 129^{\circ} 46^{\prime} 77.3^{\prime \prime}$ \\
\hline $\mathrm{Bp}-2(\mathrm{U})$ & N36 ${ }^{\circ} 44^{\prime} 05.2^{\prime \prime} \mathrm{E} 129^{\circ} 28^{\prime} 28.3^{\prime \prime}$ \\
\hline SS-1(T) & N36 $35^{\prime} 47.5^{\prime \prime E} 126^{\circ} 18^{\prime} 53.7^{\prime \prime}$ \\
\hline SS-2(T) & N36 $43^{\prime} 49.1^{\prime \prime E} 126^{\circ} 16^{\prime} 90.3^{\prime \prime}$ \\
\hline SS-3(T) & N36 $43^{\prime} 54.3^{\prime \prime E} 126^{\circ} 13^{\prime} 12.8^{\prime \prime}$ \\
\hline $0-1(G)$ & N34 ${ }^{\circ} 52^{\prime} 09.3^{\prime \prime E} 128^{\circ} 12^{\prime} 84.6^{\prime \prime}$ \\
\hline $0-2(G)$ & N34 ${ }^{\circ} 55^{\prime} 10.1^{\prime \prime E} 128^{\circ} 18^{\prime} 60.3^{\prime \prime}$ \\
\hline $0-3(G)$ & N34 54'09.7"E128 13'77.1" \\
\hline $\operatorname{Obw}(G)$ & N34 ${ }^{\circ} 47^{\prime} 25.0^{\prime \prime E} 128^{\circ} 25^{\prime} 41.7^{\prime \prime}$ \\
\hline Sgw-3(U) & N37 04'29.0"E129 24'29.9" \\
\hline Sgw-4(U) & N37 $04^{\circ} 29.0^{\prime \prime E} 129^{\circ} 24^{\prime} 29.9^{\prime \prime}$ \\
\hline
\end{tabular}

P, peat; M, mud; Ss, sea sand; S, seaweed; St, sea tangle; Sm, sea mustard; Hf, Hizikia fusiforme; Sf, Sargassum fulvellum; L, laver; Bp, black pine; Sgw, saline ground water; Sw, sea water; SS, sea salt; O, oyster; Obw, oyster boiled water; (T), Taean; (G), Goseong; (W), Wando; (U), Uljin. 
인체에 안전성과 적합성을 확인하고자 수행하였다. 따라서 본 질비교를 통한 적합성을 확인하기 위해 수행되었다.

연구는 해양치유자원으로써 피부에 적용할 안전성 여부와 품

Table 2. (A) Safety analysis results of resources with potential marine healing properties and (B) with potential marine healing properties for clinical applications

(A)

\begin{tabular}{|c|c|c|c|c|}
\hline $\begin{array}{l}\text { Sample } \\
\text { name }\end{array}$ & \multicolumn{4}{|c|}{ (ppm) } \\
\hline Safety limit & $\leq 20$ & $\leq 10$ & $\leq 5$ & $\leq 1$ \\
\hline $\mathrm{P}-1(\mathrm{~T})$ & $<0.04$ & $<0.05$ & $<0.002$ & $\begin{array}{c}0.015 \\
\pm 0.001\end{array}$ \\
\hline P-2(T) & $<0.04$ & $<0.05$ & $<0.002$ & $\begin{array}{r}0.008 \\
\pm 0.001\end{array}$ \\
\hline$M(G)$ & $<0.04$ & $<0.05$ & $<0.002$ & $\begin{array}{c}0.009 \\
\pm 0.001\end{array}$ \\
\hline$M(W)$ & $<0.04$ & $<0.05$ & $<0.002$ & $\begin{array}{c} \pm .0001 \\
0.014\end{array}$ \\
\hline $\mathrm{M}-1(\mathrm{~T})$ & $<0.04$ & $<0.05$ & $<0.002$ & $\begin{array}{c} \pm 0.001 \\
0.014\end{array}$ \\
\hline $\mathrm{M}-2(\mathrm{~T})$ & $<0.04$ & $<0.05$ & $<0.002$ & \pm 0.001 \\
\hline $\mathrm{Ss}(\mathrm{U})$ & $\begin{array}{c}0.784 \\
\pm 0.001\end{array}$ & $\begin{array}{r}3.528 \\
\pm 0.196 \\
0.968\end{array}$ & $\begin{array}{c}0.196 \\
\pm 0.001\end{array}$ & $\begin{array}{c}0.001 \\
\pm 0.001\end{array}$ \\
\hline $\mathrm{Ss}(\mathrm{G})$ & $<0.04$ & $\begin{array}{r}0.968 \\
\pm 0.001\end{array}$ & $<0.002$ & $\begin{array}{r}0.001 \\
\pm 0.001\end{array}$ \\
\hline $\mathrm{Ss}(\mathrm{W})$ & $<0.04$ & $<0.05$ & $<0.002$ & $<0.001$ \\
\hline Ss-1(T) & $<0.04$ & $<0.05$ & $<0.002$ & $<0.001$ \\
\hline Ss-2(T) & $<0.04$ & $<0.05$ & $<0.002$ & $<0.001$ \\
\hline Ss-3(T) & $<0.04$ & $<0.05$ & $<0.002$ & $<0.001$ \\
\hline S-1(St)(W) & $\begin{array}{c}0.095 \\
\pm 0.030 \\
0.147\end{array}$ & $\begin{array}{c}5.151 \\
\pm 0.143 \\
8.742\end{array}$ & $\begin{array}{c}0.181 \\
\pm 0.001 \\
0.413\end{array}$ & $\begin{array}{c}0.003 \\
\pm 0.001 \\
0.001\end{array}$ \\
\hline $\mathrm{S}-2(\mathrm{Sm})(\mathrm{W})$ & $\begin{array}{c} \pm 0.023 \\
0.081\end{array}$ & $\begin{array}{c} \pm 0.332 \\
7.304\end{array}$ & $\begin{array}{c} \pm 0.023 \\
0.244\end{array}$ & $\begin{array}{c} \pm 0.001 \\
0.002\end{array}$ \\
\hline $\mathrm{S}-\mathrm{S}(\mathrm{HT})(\mathrm{VV})$ & $\begin{array}{l} \pm 0.013 \\
0.145\end{array}$ & $\begin{array}{c} \pm 0.228 \\
9.022\end{array}$ & $\begin{array}{c} \pm 0.022 \\
0.388\end{array}$ & $\begin{array}{c} \pm 0.001 \\
0.003\end{array}$ \\
\hline $\mathrm{S}-4(\mathrm{ST})(\mathrm{V})$ & $\begin{array}{c} \pm 0.001 \\
0.550\end{array}$ & \pm 0.579 & $\begin{array}{c} \pm 0.021 \\
0.092\end{array}$ & $\begin{array}{c} \pm 0.001 \\
0.007\end{array}$ \\
\hline $\mathrm{Bp}(\mathrm{U})$ & $\begin{array}{c} \pm 0.092 \\
0.486\end{array}$ & $<0.05$ & $\begin{array}{c} \pm 0.001 \\
0.097\end{array}$ & $\begin{array}{c} \pm 0.001 \\
0.008\end{array}$ \\
\hline $\mathrm{Bp}(\mathrm{G})$ & $\begin{array}{c} \pm 0.001 \\
0.482\end{array}$ & $<0.05$ & $\begin{array}{c} \pm 0.001 \\
0.090\end{array}$ & $\begin{array}{c} \pm 0.001 \\
0.008\end{array}$ \\
\hline $\mathrm{Bp}(\mathrm{T})$ & $\begin{array}{c} \pm 0.052 \\
0.809\end{array}$ & $<0.05$ & $\begin{array}{c} \pm 0.001 \\
0.093\end{array}$ & $\begin{array}{c} \pm 0.001 \\
0.008\end{array}$ \\
\hline & $\begin{array}{c} \pm 0.108 \\
0.267\end{array}$ & -0.00 & \pm 0.001 & \pm 0.001 \\
\hline SgW-I(U) & $\begin{array}{c} \pm 0.115 \\
0.400\end{array}$ & $<0.05$ & $<0.002$ & $<0.001$ \\
\hline Sgw-2(U) & $\begin{array}{r}.4001 \\
\pm 0.001\end{array}$ & $<0.05$ & $<0.002$ & $<0.001$ \\
\hline $\mathrm{Sw}(U)$ & $\begin{array}{r}0.333 \\
\pm 0.115\end{array}$ & $<0.05$ & $<0.002$ & $<0.001$ \\
\hline $\operatorname{Sw}(G)$ & $\begin{array}{c}0.400 \\
\pm 0.200 \\
0.267\end{array}$ & $<0.05$ & $<0.002$ & $<0.001$ \\
\hline $\mathrm{Sw}(\mathrm{W})$ & $\begin{array}{c}0.267 \\
\pm 0.115 \\
0.400\end{array}$ & $<0.05$ & $<0.002$ & $<0.001$ \\
\hline Sw-1(T) & $\begin{array}{r}0.400 \\
\pm 0.001\end{array}$ & $<0.05$ & $<0.002$ & $<0.001$ \\
\hline Sw-2(T) & $\begin{array}{r}0.400 \\
\pm 0.001 \\
\end{array}$ & $\begin{array}{r}0.267 \\
\pm 0.115 \\
\end{array}$ & $<0.002$ & $<0.001$ \\
\hline
\end{tabular}

(B)

\begin{tabular}{|c|c|c|c|c|}
\hline $\begin{array}{l}\text { Sample } \\
\text { name }\end{array}$ & $\mathrm{Pb}$ & As & $\mathrm{Cd}$ & $\mathrm{Hg}$ \\
\hline Safety limit & $\leq 20$ & $\leq 10$ & $\leq 5$ & $\leq 1$ \\
\hline $\mathrm{P}-1(\mathrm{~T})$ & $\begin{array}{l}16.921 \\
\pm 0.162\end{array}$ & $\begin{array}{c}2.214 \\
\pm 0.001\end{array}$ & $<0.002$ & $\begin{array}{c}0.017 \\
\pm 0.001\end{array}$ \\
\hline $\mathrm{P}-2(\mathrm{~T})$ & $<0.04$ & $<0.05$ & $<0.002$ & $\begin{array}{r}0.006 \\
\pm 0.001\end{array}$ \\
\hline$M-3(T)$ & $<0.04$ & $\begin{array}{c}2.105 \\
\pm 0.001\end{array}$ & $<0.002$ & $\begin{array}{c}0.014 \\
\pm 0.001\end{array}$ \\
\hline $\mathrm{M}-4(\mathrm{~T})$ & $<0.04$ & $<0.05$ & $<0.002$ & $\begin{array}{c}0.012 \\
\pm 0.001 \\
0.009\end{array}$ \\
\hline$M-5(T)$ & $<0.04$ & $<0.05$ & $<0.002$ & \pm 0.001 \\
\hline S-5(Sm)(W) & $<0.04$ & $\begin{array}{c}2.278 \\
\pm 0.110 \\
2.012\end{array}$ & $\begin{array}{c}0.146 \\
\pm 0.015 \\
0.166\end{array}$ & $\begin{array}{c}0.021 \\
\pm 0.001 \\
0.025\end{array}$ \\
\hline S-6(Sm)(W) & $<0.04$ & $\begin{array}{c} \pm 0.078 \\
2.799\end{array}$ & $\begin{array}{c} \pm 0.009 \\
0.217\end{array}$ & $\begin{array}{l} \pm 0.001 \\
0.015\end{array}$ \\
\hline S-7(Sm)(W) & $<0.04$ & $\begin{array}{c} \pm 0.094 \\
1.005\end{array}$ & $\begin{array}{c} \pm 0.013 \\
0.131\end{array}$ & \pm 0.001 \\
\hline S-8(L)(W) & $<0.04$ & $\begin{array}{c}1.005 \\
\pm 0.052 \\
0.582\end{array}$ & $\begin{array}{c} \pm 0.007 \\
0.118\end{array}$ & $<0.001$ \\
\hline S-9(L)(W) & $<0.04$ & $\begin{array}{c} \pm 0.069 \\
1.045\end{array}$ & $\begin{array}{c} \pm 0.001 \\
0.134\end{array}$ & $<0.001$ \\
\hline S-10(L)(W) & $<0.04$ & \pm 0.075 & \pm 0.001 & $<0.001$ \\
\hline $\mathrm{Bp}(\mathrm{U})$ & $<0.04$ & $<0.05$ & $<0.002$ & $\begin{array}{c}0.004 \\
\pm 0.001\end{array}$ \\
\hline Bp-1(U) & $<0.04$ & $<0.05$ & $<0.002$ & $\begin{array}{r}.008 \\
\pm 0.001 \\
\end{array}$ \\
\hline $\mathrm{Bp}-2(\mathrm{U})$ & $<0.04$ & $<0.05$ & $<0.002$ & $\begin{array}{c}0.004 \\
\pm 0.001\end{array}$ \\
\hline SS-1(T) & $<0.04$ & $<0.05$ & $<0.002$ & $<0.001$ \\
\hline SS-2(T) & $<0.04$ & $<0.05$ & $<0.002$ & $<0.001$ \\
\hline SS-3(T) & $<0.04$ & $<0.05$ & $<0.002$ & $<0.001$ \\
\hline $0-1(G)$ & $\begin{array}{c}0.217 \\
\pm 0.058\end{array}$ & $\begin{array}{c}1.400 \\
\pm 0.001\end{array}$ & $\begin{array}{c}0.467 \\
\pm 0.058\end{array}$ & $\begin{array}{c}0.007 \\
\pm 0.001\end{array}$ \\
\hline $0-2(G)$ & $<0.04$ & $<0.05$ & $\begin{array}{c}0.301 \\
\pm 0.001\end{array}$ & $\begin{array}{r}0.008 \\
\pm 0.001\end{array}$ \\
\hline $0-3(G)$ & $<0.04$ & $\begin{array}{c}0.269 \\
\pm 0.029\end{array}$ & $\begin{array}{c}0.403 \\
\pm 0.050\end{array}$ & $\begin{array}{r}0.008 \\
\pm 0.001\end{array}$ \\
\hline $\operatorname{Obw}(G)$ & $<0.04$ & $\begin{array}{c}4.067 \\
\pm 0.115\end{array}$ & $<0.002$ & $<0.001$ \\
\hline Sgw-3(U) & $<0.04$ & $<0.05$ & $<0.002$ & $<0.001$ \\
\hline Sgw-4(U) & $<0.04$ & $<0.05$ & $<0.002$ & $<0.001$ \\
\hline
\end{tabular}

P, peat; M, mud; Ss, sea sand; S, seaweed; St, sea tangle; Sm, sea mustard; Hf, Hizikia fusiforme; Sf, Sargassum fulvellum; L, laver; Bp, black pine; Sgw, saline ground water; Sw, sea water; SS, sea salt; O, oyster; Obw, oyster boiled water; (T), Taean; (G), Goseong; (W), Wando; (U), Uljin. All heavy metal components are represented in the wet weight. Each value demonstrates the mean \pm standard deviation $(n=3)$. 
Table 3. (A) Suitable component analysis results of resources with potential marine healing properties and (B) with potential marine healing properties for clinical applications

(A)

\begin{tabular}{|c|c|c|c|c|}
\hline $\begin{array}{l}\text { Sample } \\
\text { name }\end{array}$ & K & \multicolumn{2}{|c|}{ (\%) } & $\mathrm{Mg}$ \\
\hline$P(C)$ & 0.035 & 0.138 & 0.057 & 0.016 \\
\hline \multirow{2}{*}{$\mathrm{P}-1(\mathrm{~T})$} & 0.416 & 0.053 & 0.424 & 0.290 \\
\hline & $\begin{array}{c} \pm 0.035 \\
0.410\end{array}$ & $\begin{array}{c} \pm 0.009 \\
0.059\end{array}$ & $\begin{array}{c} \pm 0.008 \\
0.382\end{array}$ & $\begin{array}{c} \pm 0.009 \\
0.203\end{array}$ \\
\hline $\mathrm{P}-2(\mathrm{~T})$ & \pm 0.019 & \pm 0.002 & \pm 0.009 & \pm 0.007 \\
\hline$M(C)$ & 0.790 & 0.190 & 0.352 & 0.677 \\
\hline \multirow{2}{*}{$M(G)$} & 0.977 & 0.691 & 0.219 & 0.947 \\
\hline & $\begin{array}{c} \pm 0.061 \\
0.804\end{array}$ & $\begin{array}{c} \pm 0.032 \\
0.752\end{array}$ & $\begin{array}{c} \pm 0.015 \\
0.527\end{array}$ & $\begin{array}{c} \pm 0.027 \\
0.803\end{array}$ \\
\hline$M(W)$ & $\begin{array}{c} \pm 0.013 \\
0.789\end{array}$ & $\begin{array}{c} \pm 0.023 \\
0.562\end{array}$ & $\begin{array}{c} \pm 0.011 \\
0.343\end{array}$ & $\begin{array}{c} \pm 0.015 \\
0.746\end{array}$ \\
\hline$M-1(T)$ & $\begin{array}{c} \pm 0.026 \\
0.694\end{array}$ & $\begin{array}{c} \pm 0.018 \\
0.550\end{array}$ & $\begin{array}{c} \pm 0.008 \\
0.340\end{array}$ & $\begin{array}{c} \pm 0.027 \\
0.695\end{array}$ \\
\hline$M-2(T)$ & \pm 0.012 & \pm 0.020 & \pm 0.006 & \pm 0.009 \\
\hline $\mathrm{Ss}(\mathrm{C})$ & 0.047 & 0.065 & 0.217 & 0.019 \\
\hline $\mathrm{Ss}(\mathrm{U})$ & $\begin{array}{c}0.250 \\
\pm 0.012 \\
0.759\end{array}$ & $\begin{array}{c}0.070 \\
\pm 0.005 \\
0.064\end{array}$ & $\begin{array}{c}0.070 \\
\pm 0.010 \\
0.244\end{array}$ & $\begin{array}{c}0.057 \\
\pm 0.004 \\
0.204\end{array}$ \\
\hline $\mathrm{Ss}(\mathrm{G})$ & $\begin{array}{c} \pm 0.026 \\
0.152\end{array}$ & $\begin{array}{c} \pm 0.013 \\
0.077\end{array}$ & $\begin{array}{c} \pm 0.013 \\
0.338\end{array}$ & $\begin{array}{c} \pm 0.016 \\
0.069\end{array}$ \\
\hline $\mathrm{Ss}(\mathrm{W})$ & $\begin{array}{c} \pm 0.014 \\
0.228\end{array}$ & $\begin{array}{c} \pm 0.008 \\
0.059\end{array}$ & $\begin{array}{c} \pm 0.037 \\
0.090\end{array}$ & $\begin{array}{c} \pm 0.003 \\
0.135\end{array}$ \\
\hline Ss-1(T) & $\begin{array}{c} \pm 0.018 \\
0.116\end{array}$ & $\begin{array}{c} \pm 0.002 \\
0.045\end{array}$ & $\begin{array}{c} \pm 0.007 \\
0.076\end{array}$ & $\begin{array}{c} \pm 0.010 \\
0.038\end{array}$ \\
\hline Ss-2(T) & $\begin{array}{c} \pm 0.005 \\
0.135\end{array}$ & $\begin{array}{c} \pm 0.001 \\
0.039\end{array}$ & $\begin{array}{c} \pm 0.005 \\
0.070\end{array}$ & $\begin{array}{c} \pm 0.002 \\
0.037\end{array}$ \\
\hline Ss-3(T) & \pm 0.006 & \pm 0.001 & \pm 0.001 & \pm 0.001 \\
\hline $\mathrm{S}(\mathrm{St})(\mathrm{C})$ & 3.193 & 1.581 & 0.949 & 0.568 \\
\hline $\mathrm{S}-1(\mathrm{St})(\mathrm{W})$ & $\begin{array}{c}5.996 \\
\pm 0.243 \\
6.530\end{array}$ & $\begin{array}{c}2.065 \\
\pm 0.194 \\
2.753\end{array}$ & $\begin{array}{c}0.704 \\
\pm 0.063 \\
1.000\end{array}$ & $\begin{array}{c}0.515 \\
\pm 0.046 \\
0.555\end{array}$ \\
\hline $\mathrm{S}-2(\mathrm{Sm})(\mathrm{W})$ & $\begin{array}{c} \pm 0.234 \\
3.674\end{array}$ & $\begin{array}{c} \pm 0.132 \\
1.840\end{array}$ & $\begin{array}{c} \pm 0.036 \\
0.637\end{array}$ & $\begin{array}{c} \pm 0.018 \\
0.369\end{array}$ \\
\hline \multirow{2}{*}{$\begin{array}{l}\text { S-3(Hf)(W) } \\
\text { S-4(Sf)(W) }\end{array}$} & $\begin{array}{c} \pm 0.151 \\
2.184\end{array}$ & $\begin{array}{c} \pm 0.228 \\
1.448\end{array}$ & $\begin{array}{c} \pm 0.095 \\
1.039\end{array}$ & $\begin{array}{c} \pm 0.029 \\
1.342\end{array}$ \\
\hline & \pm 0.173 & \pm 0.116 & \pm 0.116 & \pm 0.172 \\
\hline $\mathrm{Bp}(\mathrm{C})$ & 0.283 & 0.112 & 0.271 & 0.015 \\
\hline \multirow{2}{*}{$\mathrm{Bp}(\mathrm{U})$} & 0.347 & 0.154 & 0.322 & 0.147 \\
\hline & $\begin{array}{c} \pm 0.012 \\
0.319\end{array}$ & $\begin{array}{c} \pm 0.008 \\
0.032\end{array}$ & $\begin{array}{c} \pm 0.014 \\
0.361\end{array}$ & $\begin{array}{c} \pm 0.006 \\
0.097\end{array}$ \\
\hline $\mathrm{Bp}(\mathrm{G})$ & $\begin{array}{c} \pm 0.001 \\
0.277\end{array}$ & $\begin{array}{c} \pm 0.004 \\
0.083\end{array}$ & $\begin{array}{c} \pm 0.041 \\
0.290\end{array}$ & $\begin{array}{c} \pm 0.008 \\
0.118\end{array}$ \\
\hline $\mathrm{Bp}(\mathrm{T})$ & $\begin{array}{c} \pm 0.005 \\
0.519 \\
\pm 0.044\end{array}$ & $\begin{array}{c} \pm 0.003 \\
0.113 \\
\pm 0.005\end{array}$ & $\begin{array}{c} \pm 0.007 \\
0.323 \\
\pm 0.015\end{array}$ & $\begin{array}{c} \pm 0.002 \\
0.143 \\
\pm 0.016\end{array}$ \\
\hline $\operatorname{Sgw}(C)$ & 0.004 & 0.318 & 0.186 & 0.101 \\
\hline Sgw-1(U) & $\begin{array}{c}0.016 \\
\pm 0.001\end{array}$ & $\begin{array}{c}0.023 \\
\pm 0.001\end{array}$ & $<0.003$ & $<0.001$ \\
\hline Sgw-2(U) & $\begin{array}{c}0.015 \\
\pm 0.001\end{array}$ & $\begin{array}{c}0.020 \\
\pm 0.001\end{array}$ & $<0.003$ & $<0.001$ \\
\hline $\operatorname{Sw}(C)$ & 0.040 & 1.110 & 0.040 & 0.141 \\
\hline $\operatorname{Sw}(U)$ & $\begin{array}{c}0.042 \\
\pm 0.001 \\
0.042\end{array}$ & $\begin{array}{c}0.902 \\
\pm 0.016 \\
0.908\end{array}$ & $\begin{array}{c}0.036 \\
\pm 0.001 \\
0.035\end{array}$ & $\begin{array}{c}0.118 \\
\pm 0.002 \\
0.119\end{array}$ \\
\hline $\operatorname{Sw}(G)$ & $\begin{array}{c} \pm 0.001 \\
0.043\end{array}$ & $\begin{array}{c} \pm 0.034 \\
0.939\end{array}$ & $\begin{array}{c} \pm 0.002 \\
0.036\end{array}$ & $\begin{array}{c} \pm 0.005 \\
0.123\end{array}$ \\
\hline Sw(W) & $\begin{array}{c} \pm 0.001 \\
0.042\end{array}$ & $\begin{array}{c} \pm 0.026 \\
0.889\end{array}$ & $\begin{array}{c} \pm 0.001 \\
0.035\end{array}$ & $\begin{array}{c} \pm 0.003 \\
0.116\end{array}$ \\
\hline Sw-1(T) & $\begin{array}{c} \pm 0.001 \\
0.041\end{array}$ & $\begin{array}{c} \pm 0.060 \\
0.845\end{array}$ & $\begin{array}{c} \pm 0.002 \\
0.034\end{array}$ & $\begin{array}{c} \pm 0.006 \\
0.113\end{array}$ \\
\hline Sw-2(T) & \pm 0.001 & \pm 0.032 & \pm 0.002 & \pm 0.003 \\
\hline
\end{tabular}

(B)

\begin{tabular}{|c|c|c|c|c|}
\hline $\begin{array}{l}\text { Sample } \\
\text { name }\end{array}$ & K & \multicolumn{2}{|c|}{ (\%) } & Mg \\
\hline$P(C)$ & 0.035 & 0.138 & 0.057 & 0.016 \\
\hline$P-1(T)$ & $\begin{array}{c}0.293 \\
\pm 0.010\end{array}$ & $\begin{array}{c}0.135 \\
\pm 0.010\end{array}$ & $\begin{array}{c}0.632 \\
\pm 0.013\end{array}$ & $\begin{array}{r}0.389 \\
\pm 0.004\end{array}$ \\
\hline$P-2(T)$ & $\begin{array}{c}0.199 \\
\pm 0.005\end{array}$ & $\begin{array}{c}0.094 \\
\pm 0.094\end{array}$ & $\begin{array}{c}0.404 \\
\pm 0.007\end{array}$ & $\begin{array}{c}0.177 \\
\pm 0.005\end{array}$ \\
\hline$M(C)$ & 0.790 & 0.190 & 0.352 & 0.677 \\
\hline$M-3(T)$ & $\begin{array}{c}0.616 \\
\pm 0.018 \\
0.563\end{array}$ & $\begin{array}{c}0.994 \\
\pm 0.022 \\
1.745\end{array}$ & $\begin{array}{c}0.401 \\
\pm 0.008 \\
0.345\end{array}$ & $\begin{array}{c}1.351 \\
\pm 0.004 \\
1.173\end{array}$ \\
\hline $\mathrm{M}-4(\mathrm{~T})$ & $\begin{array}{c} \pm 0.048 \\
0.451\end{array}$ & $\begin{array}{c} \pm 0.118 \\
0.992\end{array}$ & $\begin{array}{c} \pm 0.015 \\
0.335\end{array}$ & $\begin{array}{c} \pm 0.063 \\
0.915\end{array}$ \\
\hline$M-5(T)$ & $\begin{array}{c} \pm 0.017 \\
0.564\end{array}$ & $\begin{array}{c} \pm 0.031 \\
0.432\end{array}$ & $\begin{array}{c} \pm 0.013 \\
0.084\end{array}$ & $\begin{array}{c} \pm 0.039 \\
0.097\end{array}$ \\
\hline $\mathrm{S}(\mathrm{Sm})(\mathrm{C})$ & $\begin{array}{c} \pm 0.129 \\
0.530\end{array}$ & $\begin{array}{c} \pm 0.045 \\
6.855\end{array}$ & $\begin{array}{c} \pm 0.006 \\
0.902\end{array}$ & $\begin{array}{c} \pm 0.004 \\
0.303\end{array}$ \\
\hline S-5(Sm)(W) & $\begin{array}{c} \pm 0.002 \\
0.605\end{array}$ & $\begin{array}{c} \pm 0.035 \\
8.352\end{array}$ & $\begin{array}{c} \pm 0.008 \\
1.078\end{array}$ & $\begin{array}{c} \pm 0.003 \\
0.370\end{array}$ \\
\hline S-6(Sm)(W) & $\begin{array}{c} \pm 0.006 \\
0.889\end{array}$ & $\begin{array}{l} \pm 0.212 \\
12.817\end{array}$ & $\begin{array}{c} \pm 0.033 \\
0.772\end{array}$ & $\begin{array}{c} \pm 0.031 \\
0.300\end{array}$ \\
\hline S-7(Sm)(W) & $\begin{array}{c} \pm 0.077 \\
1.809\end{array}$ & $\begin{array}{r} \pm 0.172 \\
0.531\end{array}$ & $\begin{array}{r} \pm 0.062 \\
0.401\end{array}$ & $\begin{array}{c} \pm 0.008 \\
0.350\end{array}$ \\
\hline $\mathrm{S}(\mathrm{L})(\mathrm{C})$ & $\begin{array}{c} \pm 0.018 \\
4.319\end{array}$ & $\begin{array}{c} \pm 0.006 \\
0.872\end{array}$ & $\begin{array}{r} \pm 0.010 \\
0.231\end{array}$ & $\begin{array}{c} \pm 0.005 \\
0.382\end{array}$ \\
\hline$S-8(L)(W)$ & $\begin{array}{l} \pm 0.174 \\
3.969\end{array}$ & $\begin{array}{r} \pm 0.012 \\
0.958\end{array}$ & $\begin{array}{c} \pm 0.016 \\
0.201\end{array}$ & $\begin{array}{c} \pm 0.005 \\
0.373\end{array}$ \\
\hline S-10(L)(W) & $\begin{array}{l} \pm 0.127 \\
3.912\end{array}$ & $\begin{array}{c} \pm 0.025 \\
0.730\end{array}$ & $\begin{array}{c} \pm 0.003 \\
0.278\end{array}$ & $\begin{array}{c} \pm 0.003 \\
0.371\end{array}$ \\
\hline $\mathrm{Bp}(\mathrm{C})$ & \pm 0.213 & \pm 0.008 & \pm 0.023 & \pm 0.008 \\
\hline Dpl(c) & 0.283 & $\begin{array}{l}0.112 \\
0.228\end{array}$ & $\begin{array}{r}0.271 \\
0.225\end{array}$ & $\begin{array}{l}0.015 \\
0.177\end{array}$ \\
\hline $\mathrm{Bp}(\mathrm{U})$ & $\begin{array}{c}0.561 \\
\pm 0.029 \\
0.383\end{array}$ & $\begin{array}{r}.228 \\
\pm 0.010 \\
0.148\end{array}$ & $\begin{array}{r}.425 \\
\pm 0.006 \\
0.598\end{array}$ & $\begin{array}{c}0.171 \\
\pm 0.005 \\
0.551\end{array}$ \\
\hline Bp-1(U) & $\begin{array}{r} \pm 0.012 \\
0.498\end{array}$ & $\begin{array}{c} \pm 0.002 \\
0.283\end{array}$ & $\begin{array}{c} \pm 0.002 \\
0.551\end{array}$ & $\begin{array}{c} \pm 0.011 \\
0.183\end{array}$ \\
\hline$B p-2(U)$ & $\begin{array}{c} \pm 0.015 \\
0.181\end{array}$ & $\begin{array}{l} \pm 0.008 \\
36.363\end{array}$ & $\begin{array}{c} \pm 0.011 \\
0.133\end{array}$ & $\begin{array}{c} \pm 0.006 \\
0.603\end{array}$ \\
\hline $\mathrm{SS}(\mathrm{C})$ & $\begin{array}{c} \pm 0.018 \\
0.354\end{array}$ & $\begin{array}{l} \pm 0.440 \\
24.773\end{array}$ & $\begin{array}{c} \pm 0.030 \\
0.239\end{array}$ & $\begin{array}{c} \pm 0.061 \\
1.574\end{array}$ \\
\hline SS-1( & $\begin{array}{c} \pm 0.004 \\
0.242\end{array}$ & $\begin{array}{l} \pm 0.877 \\
27.668\end{array}$ & $\begin{array}{c} \pm 0.011 \\
0.224\end{array}$ & $\begin{array}{c} \pm 0.055 \\
1.157\end{array}$ \\
\hline SS-2(T) & $\begin{array}{r} \pm 0.017 \\
0.168\end{array}$ & $\begin{array}{r} \pm 0.178 \\
30.029\end{array}$ & $\begin{array}{c} \pm 0.022 \\
0.248\end{array}$ & $\begin{array}{c} \pm 0.044 \\
0.794\end{array}$ \\
\hline SS-3( & \pm 0.017 & \pm 0.671 & $\begin{array}{c} \pm 0.003 \\
0.840\end{array}$ & \pm 0.025 \\
\hline $\mathrm{O}(\mathrm{C})$ & $\begin{array}{c}0.129 \\
\pm 0.031 \\
1.098\end{array}$ & $\begin{array}{c}2.186 \\
\pm 0.041 \\
1.221\end{array}$ & $\begin{array}{c}0.840 \\
\pm 0.021 \\
0.138\end{array}$ & $\begin{array}{c}0.299 \\
\pm 0.005 \\
0.215\end{array}$ \\
\hline & $\begin{array}{c} \pm 0.091 \\
1.095\end{array}$ & $\begin{array}{c} \pm 0.084 \\
1.213\end{array}$ & $\begin{array}{r} \pm 0.007 \\
0.052\end{array}$ & $\begin{array}{r} \pm 0.012 \\
0.188\end{array}$ \\
\hline $0-2(G)$ & $\begin{array}{c} \pm 0.067 \\
1.069\end{array}$ & $\begin{array}{c} \pm 0.033 \\
1.197\end{array}$ & $\begin{array}{c} \pm 0.008 \\
0.194\end{array}$ & $\begin{array}{r} \pm 0.015 \\
0.186\end{array}$ \\
\hline $0-3(\mathrm{G})$ & \pm 0.083 & \pm 0.040 & \pm 0.006 & \pm 0.014 \\
\hline $\operatorname{Obw}(G)$ & $\begin{array}{c}1.113 \\
\pm 0.033\end{array}$ & $\begin{array}{c}3.004 \\
\pm 0.109\end{array}$ & $\begin{array}{c}0.115 \\
\pm 0.023\end{array}$ & $\begin{array}{c}0.354 \\
\pm 0.013\end{array}$ \\
\hline $\operatorname{Sgw}(\mathrm{C})$ & 0.004 & 0.318 & 0.186 & 0.101 \\
\hline Sgw-3(U) & $\begin{array}{c}0.018 \\
\pm 0.001 \\
0.576\end{array}$ & $\begin{array}{c}0.394 \\
\pm 0.020 \\
4.270\end{array}$ & $\begin{array}{c}0.183 \\
\pm 0.002 \\
1.831\end{array}$ & $\begin{array}{c}0.081 \\
\pm 0.001 \\
3.235\end{array}$ \\
\hline Sgw-4(U) & \pm 0.019 & \pm 0.151 & \pm 0.050 & \pm 0.091 \\
\hline
\end{tabular}


P, peat; M, mud; Ss, sea sand; S, seaweed; St, sea tangle; Sm, sea mustard; Hf, Hizikia fusiforme; Sf, Sargassum fulvellum; L, laver; Bp, black pine; Sgw, saline ground water; Sw, sea water; SS, sea salt; O, oyster; Obw, oyster boiled water; (T), Taean; (G), Goseong; (W), Wando; (U), Uljin.

All useful components except Sgw, Sw, SS and Obw are represented as dry weight.

Each value demonstrates the mean \pm standard deviation $(n=3)$.

\section{Methods}

\section{1. 시료 채취}

해양치유 가능자원은 2018년 3월, 경북 울진, 경남 고성, 전 남 완도, 충남 태안 등 총 4 개 지역, 7 종을 대상으로 시료를 채취 하였다(Table 1A). 울진은 해사, 해송, 염지하수, 해수 등 4 종을, 고성은 머드, 해사, 해송, 해수, 등 4 종을, 완도는 머드, 해사, 해 조류(다시마, 미역, 톳, 모자반), 해송, 해수 등 5 종을, 태안은 피 트, 머드, 해사, 해송, 해수, 등 5 종을 대상으로 시료를 채취하였 다.

또한 임상적용 해양치유자원은 2019 년 4 월에 동일한 4 개 지역 에서 시료를 채취하였고, 해양치유 가능자원에서 해수를 제외한 지역 특화자원인 소금, 굴, 굴자숙수 등을 포함하여 총 9 종에 대 하여 시료를 채취하였다(Table 1B). 울진은 해송, 염지하수 등 2 종을, 고성은 굴, 굴자숙수 등 2 종을, 완도는 미역, 김 등 2 종을, 태안은 피트, 머드, 소금 등 3 종을 대상으로 시료를 채취하였다.

시료 채취방법은 4 개 지역의 정확한 자원의 위치를 확보하기 위해 GPS좌표를 획득하였고, 이 중 고체시료는 시료샘플러를 이 용하여 채취 후, 지퍼백에 담고 즉시 밀봉하고 아이스박스에 냉 장 보관하여 실내로 신속히 이송하였으며, 액체시료는 제품상태 의 경우 그대로 이송하였고, 시료 채취 상태에 따라 코니칼튜브 에 각각 $100 \mathrm{~mL}(50 \mathrm{~mL} \times 2$ 개)씩 담아 밀봉 후, 아이스박스에 냉장 보관하여 실내로 신속히 옮겼다.

\section{2. 시료 전처리}

시료 조제는 건조기에서 $60^{\circ} \mathrm{C}, 24 \mathrm{~h}$ 이상으로 건조한 피트, 머드 및 해사 등 고체시료를 고무망치로 파쇄하고, $2 \mathrm{~mm}$ 체 및 $0.5 \mathrm{~mm}$ 체에 통과시켜 분석용 시료로 조제하였으며, 동일하게 건조한 해조류, 해송, 소금, 굴, 등 고체시료를 분쇄기로 분쇄하 여 분석용 시료로 조제하였다. 액체시료인 염지하수, 굴자숙수, 해수 등은 별도 전처리 없이 그대로 시험에 사용하였다.

시료의 분해는 상기 조제된 시료 $0.5 \mathrm{~g}$ 을 평량하여 마이크로웨 이브용 전용튜브에 넣고, 질산 $12 \mathrm{~mL}$ 를 넣는다. 시료를 넣은 전 용튜브는 후드 안에서 발생 가스를 제거하고, 마이크로웨이브 시 료전처리장비(MARS Xpress; CEM corporation, USA)로 시 료를 분해한다. 분해가 끝난 분해액은 No. 6 여과지로 여과하여 $100 \mathrm{~mL}$ 메스플라스크에 넣고, 물을 표선에 맞춰 검액(200배 희 석)으로 시험하였다. 공시액은 상기 방법과 동일하게 별도로 만 들어 검액과 함께 시험하였다.

\section{3. 중금속 분석}

중금속은 대한약전의 명시된 일반시험법을 적용하여 유도결 합플라즈마분광분석기로 분석하였다(Hu et al., 2005; Jung et al., 2007; Jung et al., 2011; Park et al., 2014). 유도결합플 라즈마분광분석기(Optima 7000DV; PerkinElmer, USA)는 납 $(\mathrm{Pb})$, 비소 $(\mathrm{As})$, 카드뮴 $(\mathrm{Cd})$ 등 각 중금속 표준원액 $(1,000 \mathrm{mg} /$ $\mathrm{L})$ 을 $0.5 \mathrm{~mol} / \mathrm{L}$ 질산을 사용하여 적정 농도로 희석하여 검량선 을 작성하고, 공시액으로 보정하여 검액의 흡광도를 측정하였다. 이때 납, 비소의 표준용액은 $0.1 \mathrm{mg} / \mathrm{L}, 0.5 \mathrm{mg} / \mathrm{L}, 1.0 \mathrm{mg} / \mathrm{L}$ 로 조제하였고, 카드뮴은 $0.01 \mathrm{mg} / \mathrm{L}, 0.05 \mathrm{mg} / \mathrm{L}, 0.10 \mathrm{mg} / \mathrm{L}$ 조 제하여 시험하였다. 또한 수은 $(\mathrm{Hg})$ 분석을 위한 시료는 강열 방 냉한 보트를 저울에 올려놓고 무게를 0 으로 맞춘 다음, 검체 0.1 $\mathrm{g}$ 을 보트에 넣고 정확한 무게를 기록하였다. 시료는 수은분석기 (Hydra II; Teledyne Leeman Labs사)용 보트를 $300^{\circ} \mathrm{C}, 20 \mathrm{~s}$ 동안 건조 후, $600^{\circ} \mathrm{C}$ 에서 $1 \mathrm{~min}$ 동안 열분해하여 수은 함량을 분석하였다.

\section{4. 유용성분 비교분석}

유용성분 또한 대한약전 일반시험법을 적용하여 유도결합플라 즈마분광분석기로 분석하였다(Kwak et al,, 2010; Kim et al., 2014c). 유도결합플라즈마분광분석기는 칼륨 $(\mathrm{K})$, 나트륨 $(\mathrm{Na})$, 칼 슘(Ca), 마그네슘 $(\mathrm{Mg})$ 등 각 미네랄 성분의 표준원액 $(1,000 \mathrm{mg} /$ $\mathrm{L})$ 을 $0.5 \mathrm{~mol} / \mathrm{L}$ 질산을 사용하여 적정 농도로 희석하여 검량선을 작성하고, 공시액으로 보정하여 검액의 흡광도를 측정하였다. 이 때 칼륨, 나트륨, 칼슘, 마그네슘의 표준용액은 $0.09 \mathrm{mg} / \mathrm{L}, 0.90$ $\mathrm{mg} / \mathrm{L}, 9.00 \mathrm{mg} / \mathrm{L}$ 로 동일하게 조제하여 사용하였다.

\section{5. 통계 분석}

본 실험 결과는 GraphPad 프로그램(GraphPad Software, $\mathrm{USA})$ 을 이용하여 평균값과 표준편차를 산출하였다. 각 군간의 유의성은 일원분산분석(one-way analysis of variance, oneway ANOVA)을 시행 후 모든 처리 값의 차이는 신뢰수준 95\% $(p<0.05)$ 로 검증하였다.

\section{Results}

\section{1. 중금속 분석}

해양치유 가능자원과 임상적용 해양치유자원의 중금속 분석결 과는 식품의약품안전처 에 고시된「유통화장품 안전관리 기준 
A

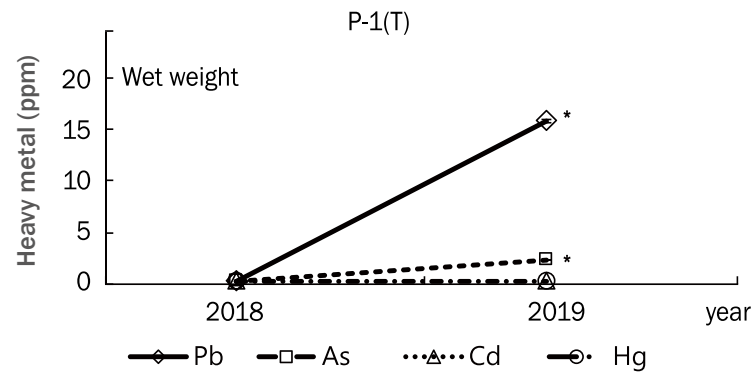

C

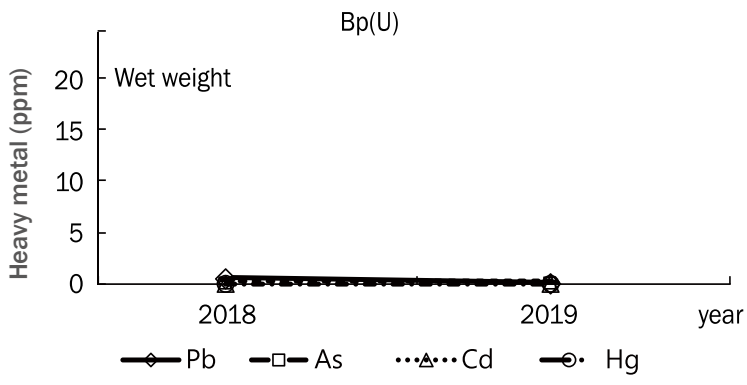

$\mathrm{P}-2(\mathrm{~T})$

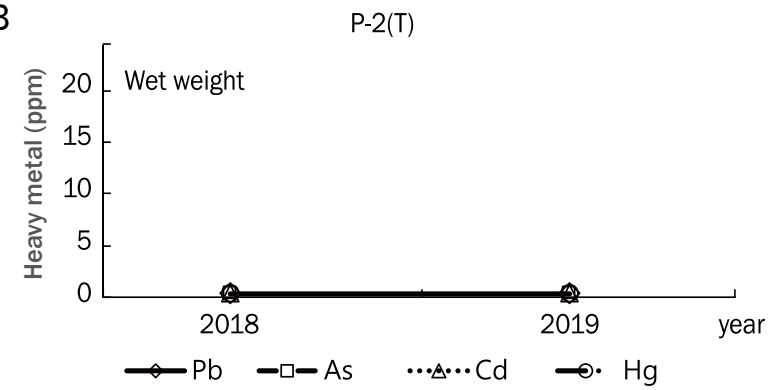

Figure 1. Analysis on the variation of heavy metal in marine healing resources by year.

Each bar demonstrates the mean \pm standard deviation $(\mathrm{n}=3)$. One-way ANOVA was used to perform this statistical analysis $\left({ }^{*} p<0.05\right) . \mathrm{P}$, peat; Bp, black pine; (T), Taean; (U), Uljjn.

에 의거하여 납은 $20 \mathrm{ppm}$ 이하, 비소는 $10 \mathrm{ppm}$ 이하, 카드뮴은 5 $\mathrm{ppm}$ 이하, 수은은 $1 \mathrm{ppm}$ 이하로 안전성 적합 여부를 확인하였다.

해양치유 가능자원의 중금속 분석결과는 Table $2 \mathrm{~A}$ 와 같다. 우 선 해양치유 가능자원 중에서 피트, 머드, 해사, 해조류, 해송, 염 지하수 및 해수 등의 중금속 량은 식품의약 품안전처의 안전성 기준보다 모두 낮거나, 극미량 수준인 것으로 확인되어진 반면 해 조류(미역, 다시마, 톳, 모자반)의 중금속 중 비소 함량은 안전성 기준보다는 낮은 수준이지만 비교적 높은 경향을 나타냈다.

또한 임상적용 해양치유자원의 중금속 분석결과는 Table $2 \mathrm{~B}$ 와 같다. 임상적용 해양치유자원 중에서 피트, 머드, 미역, 김, 해송, 굴, 굴자술수 및 염지하수 등의 중금속 량은 식품의약품안전처 의 안전성 기준보다 모두 낮거나, 극미량 수준인 것으로 확인되어 진 반면 일부 피트 시료에 대하여 중금속 중 납 함량은 안전성 기 준보다 낮은 수준이지만 비교적 높은 경향을 나타냈다.

\section{2. 품질 비교분석}

해양치유 가능자원의 품질 비교분석 결과는 Table $3 \mathrm{~A}$ 과 같 다. 피트의 칼륨, 칼슘, 마그네슘 함량은 $\mathrm{P}-1(\mathrm{~T}), \mathrm{P}-2(\mathrm{~T})$ 의 2 개 시료 모두 핀란드의 대조구(피트) 보다 높은 수준이었지만 나트
륨 함량은 낮은 수준이었다. 머드의 나트륨 함량은 $\mathrm{M}(\mathrm{G}), \mathrm{M}(\mathrm{W})$, $\mathrm{M}-1(\mathrm{~T}), \mathrm{M}-2(\mathrm{~T})$ 의 4 개 시료 모두 보령의 대조구(머드)보다 높 은 수준이었고 칼륨, 마그네슘 함량은 $\mathrm{M}(\mathrm{G}), \mathrm{M}(\mathrm{W}), \mathrm{M}-1(\mathrm{~T})$, $\mathrm{M}-2(\mathrm{~T})$ 의 4 개 시료 모두 유사한 수준이었으며, 칼슘 함량은 $\mathrm{M}(\mathrm{W})$ 시료가 높은 수준이었지만 $\mathrm{M}(\mathrm{G}), \mathrm{M}-1(\mathrm{~T}), \mathrm{M}-2(\mathrm{~T})$ 의 3 개 시료에서 유사하거나 낮은 수준이었다. 해사의 칼륨, 마그네슘 함 량은 $\mathrm{Ss}(\mathrm{U}), \mathrm{Ss}(\mathrm{G}), \mathrm{Ss}(\mathrm{W}), \mathrm{Ss}-1(\mathrm{~T}), \mathrm{Ss}-2(\mathrm{~T}), \mathrm{Ss}-3(\mathrm{~T})$ 의 6 개 시료 모두 완도의 대조구(해사) 보다 높은 수준이었고 나트륨 함 량은 $\mathrm{Ss}(\mathrm{U}), \mathrm{Ss}(\mathrm{G}), \mathrm{Ss}(\mathrm{W}), \mathrm{Ss}-1(\mathrm{~T}), \mathrm{Ss}-2(\mathrm{~T}), \mathrm{Ss}-3(\mathrm{~T})$ 등 6 개 시료 모두 유사한 수준이었으며, 칼슘 함량은 $\mathrm{Ss}(\mathrm{G}), \mathrm{Ss}(\mathrm{W})$ 의 2 개 시료에서 높은 수준이었지만, $\mathrm{Ss}(\mathrm{U}), \mathrm{Ss}-1(\mathrm{~T}), \mathrm{Ss}-2(\mathrm{~T})$, $\mathrm{Ss}-3(\mathrm{~T})$ 의 4 개 시료에서는 낮은 수준이었다(Cho, 1988). 해 조류의 칼륨, 나트륨, 칼슘 함량은 $\mathrm{S}-1(\mathrm{St}(\mathrm{W})), \mathrm{S}-2(\mathrm{Sm}(\mathrm{W}))$, $\mathrm{S}-3(\mathrm{Hf}(\mathrm{W})), \mathrm{S}-4(\mathrm{Sf}(\mathrm{W}))$ 의 4 개 시료 모두 완도의 대조구(다 시마)와 유사하거나 다소 높은 수준이었고 마그네슘 함량은 $\mathrm{S}-1(\mathrm{St}(\mathrm{W})), \mathrm{S}-2(\mathrm{Sm}(\mathrm{W})), \mathrm{S}-3(\mathrm{Hf}(\mathrm{W}))$ 의 3 개 시료에서 유사 한 수준이었지만, $\mathrm{S}-4(\mathrm{Sf}(\mathrm{W}))$ 시료는 높은 수준이었다. 해송의 칼 륨 함량은 $\mathrm{Bp}(\mathrm{T})$ 시료가 순천의 대조구(해송) 보다 높은 수준이었 고 $\mathrm{Bp}(\mathrm{U}), \mathrm{Bp}(\mathrm{G}), \mathrm{Bp}(\mathrm{W})$ 의 3 개 시료에서 유사한 수준이었으며, 

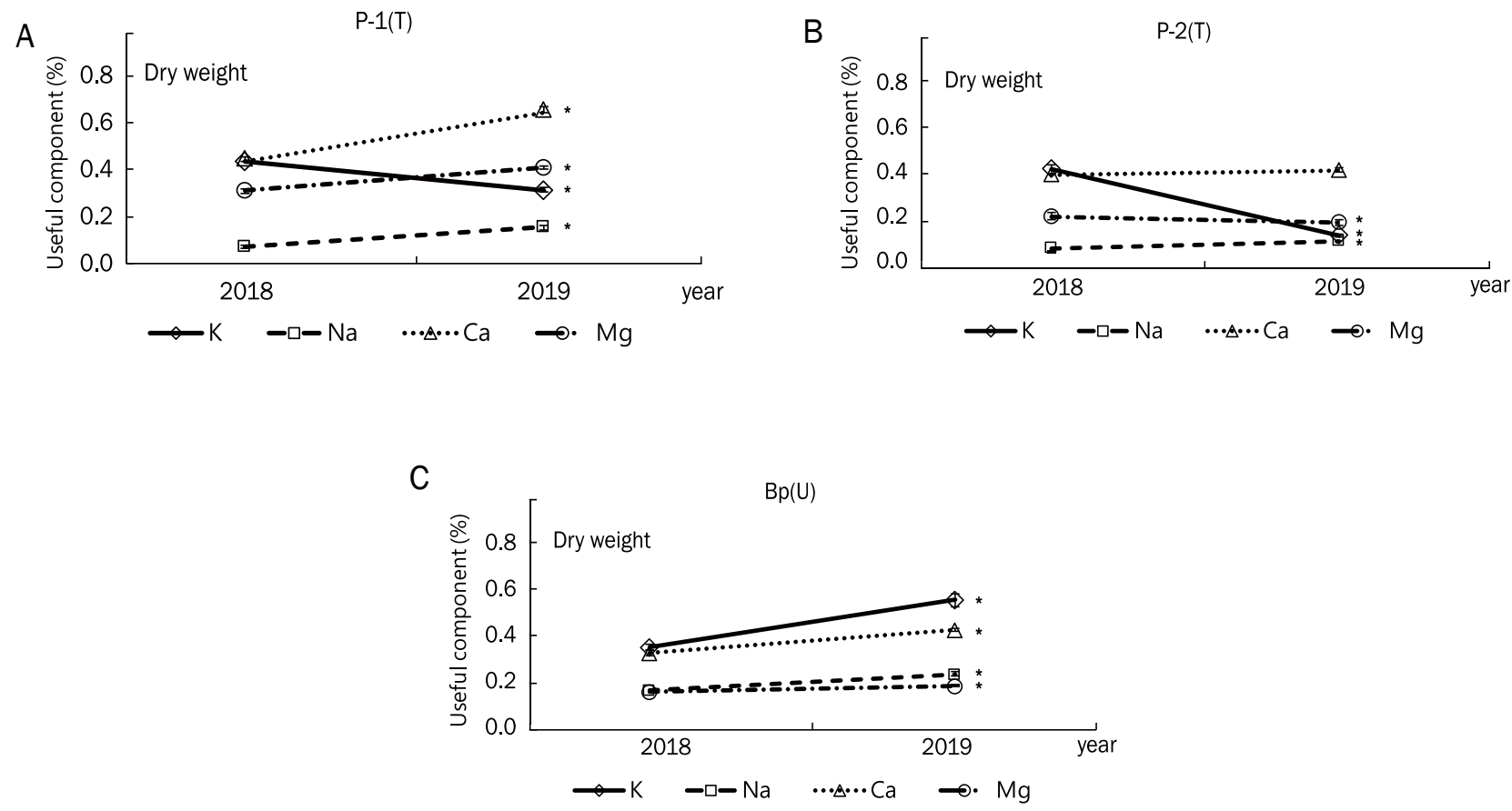

Figure 2. Variation analysis of useful components in marine healing resources by year.

Each bar demonstrates the mean \pm standard deviation $(\mathrm{n}=3)$. One-way ANOVA was used to perform this statistical analysis $\left({ }^{*} p<0.05\right)$. $\mathrm{P}$, peat; Bp, black pine; (T), Taean; (U), Uljjn.

나트륨 함량은 $\mathrm{Bp}(\mathrm{U}), \mathrm{Bp}(\mathrm{W}), \mathrm{Bp}(\mathrm{T})$ 의 3 개 시료에서 유사한 수 준이었지만, $\mathrm{Bp}(\mathrm{G})$ 시료는 낮은 수준이었다. 또한 마그네슘 함량 은 $\mathrm{Bp}(\mathrm{U}), \mathrm{Bp}(\mathrm{G}), \mathrm{Bp}(\mathrm{W}), \mathrm{Bp}(\mathrm{T})$ 등 4 개 시료 모두 순천의 대조구 (해송) 보다 높은 수준이었고 칼슘 함량은 $\mathrm{Bp}(\mathrm{U}), \mathrm{Bp}(\mathrm{G}), \mathrm{Bp}(\mathrm{W})$, $\mathrm{Bp}(\mathrm{T})$ 등 4 개 시료 모두 유사한 수준이었다. 염지하수의 칼륨 함 량은 $\mathrm{Sgw}-1(\mathrm{U}), \mathrm{Sgw}-2(\mathrm{U})$ 2개 시료 모두 울진의 대조구(염지 하수)보다 높은 수준이었고, 나트륨, 칼슘, 마그네슘 함량은 낮은 수준인 것으로 확인되었다. 해수의 칼륨, 나트륨, 칼슘, 마그네슘 함량은 $\mathrm{Sw}(\mathrm{U}), \mathrm{Sw}(\mathrm{G}), \mathrm{Sw}(\mathrm{W}), \mathrm{Sw}-1(\mathrm{~T}), \mathrm{Sw}-2(\mathrm{~T})$ 의 5 개 시료 모두 울진의 대조구(해수)와 유사한 수준인 것으로 확인되었다.

또한 임상적용 해양치유자원의 품질 비교분석 결과는 Table $3 \mathrm{~B}$ 과 같다. 피트의 칼륨, 칼슘, 마그네슘 함량은 $\mathrm{P}-1(\mathrm{~T}), \mathrm{P}-2(\mathrm{~T})$ 의 2 개 시료 모두 핀란드의 대조구(피트)보다 높은 수준이고 나트륨 함량은 유사하거나 낮은 수준으로 확인되었다. 머드의 나트륨, 마 그네슘 함량은 $\mathrm{M}-3(\mathrm{~T}), \mathrm{M}-4(\mathrm{~T}), \mathrm{M}-5(\mathrm{~T})$ 의 3 개 시료 모두 보령 의 대조구(머드)보다 높은 수준으로 확인되었고, 칼륨, 칼슘 함량 은 유사하거나 낮은 수준으로 확인되었다. 미역의 칼륨, 나트륨, 칼슘, 마그네슘 함량은 $\mathrm{S}-5(\mathrm{Sm})(\mathrm{W}), \mathrm{S}-6(\mathrm{Sm})(\mathrm{W}), \mathrm{S}-7(\mathrm{Sm})$ (W)의 3 개 시료 모두 완도의 대조구(미역) 보다 높은 수준으로 확 인되었다(Choi et al., 2008). 김의 칼륨, 나트륨 함량은 S-8(L)
(W), S-9(L)(W), S-10(L)(W)의 3 개 시료 모두 완도의 대조구 (김) 보다 높은 수준이지만, 마그네슘과 칼슘 함량은 유사하거나 낮은 수준으로 확인되었다(Kim et al., 2014b). 해송의 칼륨, 나 트륨, 칼슘, 마그네슘 함량은 $\mathrm{Bp}(\mathrm{U}), \mathrm{Bp}-1(\mathrm{U}), \mathrm{Bp}-2(\mathrm{U})$ 의 3 개 시료 모두 순천의 대조구(해송) 보다 높은 수준으로 확인되었다. 소금의 칼륨, 칼슘, 마그네슘 함량은 $\mathrm{SS}-1(\mathrm{~T}), \mathrm{SS}-2(\mathrm{~T}), \mathrm{SS}-$ 3 (T)의 3 개 시료 모두 국내산 대조구(소금) 보다 높은 수준이지만, 나트륨 함량은 낮은 수준으로 확인되었다(Kim et al., 2014a), 굴 의 칼륨 함량은 $\mathrm{O}-1(\mathrm{G}), \mathrm{O}-2(\mathrm{G}), \mathrm{O}-3(\mathrm{G})$ 의 3 개 시료 모두 통영 의 대조구(굴)와 유사한 수준이나, 나트륨, 칼슘, 마그네슘 함량은 낮은 수준인 것으로 확인되었다(Lee et al., 2012). 굴자숙수의 칼륨, 나트륨, 마그네슘 함량은 통영의 대조구(굴) 보다 높은 수준 이지만, 칼슘 함량은 낮은 수준인 것으로 확인되었다. 염지하수의 칼륨 등 4성분의 함량은 $\mathrm{Sgw}-4(\mathrm{U})$ 시료에서 모두 울진의 대조구 (염지하수) 보다 높은 수준인 것으로 확인되었고 $\mathrm{Sgw}-3(\mathrm{U})$ 시료 에서 유사한 수준인 것으로 확인되었다.

\section{3. 중금속 및 유용성분 변화량 분석}

해양치유 가능자원(2018년)과 임상적용 해양치유자원(2019년) 중 피트와 해송은 동일 지역에서 채취한 자원에 대하여 중금속과 
유용성분 함량의 변화량을 분석하였다.

피트와 해송의 중금속 변화량은 Figure 1 과 같다. $\mathrm{P}-1(\mathrm{~T})$ 의 납 성분은 통계적으로 유의적인 차이를 보이며 증가하였고, 비 소 성분 또한 통계적으로 유의적인 차이를 보이며 증가한 반면, $\mathrm{P}-2(\mathrm{~T})$ 와 $\mathrm{Bp}(\mathrm{U})$ 의 중금속의 변화가 없는 것으로 확인되었다.

피트와 해송의 유용성분 변화량은 Figure 2 와 같다. 피트의 나 트륨, 마그네슘 성분은 통계적으로 유의적인 차이를 보이며 증가 한 반면, 칼륨 성분은 통계적으로 유의적인 차이를 보이며 오히려 감소하는 것으로 확인되었다. 또한 해송은 칼륨 등 모든 성분이 통 계적으로 유의적인 차이를 보이며 증가하는 것으로 확인되었다.

\section{Conclusion}

본 연구는 울진, 고성, 완도 및 태안 등 4 개 지역에서 채취한 해 양치유자원 10 종의 시료에 대하여 중금속 분석결과를 통해 안전성 과 유용성분 비교분석 결과를 통해 적합성을 확인하였다.

그 결과, 해양치유자원의 중금속 분석결과는 식약처에서 제시한 모든 성분이 안전성 기준보다 낮거나 극미량 수준인 것으로 확인되 었다. 단, 해조류(다시마, 미역, 톳, 모자반)에 포함된 비소 성분과 일부 피트 시료의 납 성분이 식약처 안전성 기준보다는 낮은 수준 이지만 비교적 높은 경향을 보여 체계적인 관리·감독이 필요한 자 원으로 확인되었다. 또한 유용성분 변화량 분석결과를 보면 피트 의 칼륨 성분이 통계적으로 유의성이 있는 감소 경향을 보여 향후 지속적인 모니터링과 그에 따른 원인 규명이 필요할 것으로 예상된 다.

이상의 결과를 종합해 볼 때, 해양치유자원의 안전성 및 품질 비 교분석은 식약처 유통화장품 안전관리 기준에 모든 안전하고 해양 치유 목적으로 적합할 수 있는 자원으로 확인되었다. 하지만 향후 해양치유자원은 해양산업 전반에 걸쳐 산·학·연·관의 지속적이고 보다 체계적인 연구·관리·감독 등을 통하여 보다 안전하고 해양치 유 목적으로 적합한 자원으로 관리되어야 할 것이다.

\section{Acknowledgements}

본 연구는 해양수산부에서 지원하는 2017년도 해양수산기술 지 역특성화사업(과제번호 20170242)의 연구수행으로 인한 결과물임 을 밝힙니다.

\section{Author's contribution}

BLK performed resource surveys and experiments, analyzed data, and wrote the manuscript. YHC performed research on the information of testing methods and resources. HSL supervised the project and YGJ conducted resource surveys and all aspects of analysis and experimental design. YGJ wrote the manuscript with assistance from HSL All tables and figures are created by the authors and the co-authors.

\section{Author details}

Byung-Loc Kim (Researcher), Center of Natural Resources Research, Jeonnam Bioindustry Foundation, 288 Woodland-gil, Anyang-myeon, Jangheung-gun, Jeollanam-do 59338, Korea; Yun-Hee Choi (Researcher), Center of Natural Resources Research, Jeonnam Bioindustry Foundation, 288 Woodland-gil, Anyangmyeon, Jangheung-gun, Jeollanam-do 59338, Korea; Hak-Sung Lee (Director), Center of Natural Resources Research, Jeonnam Bioindustry Foundation, 288 Woodlandgil, Anyang-myeon, Jangheung-gun, Jeollanam-do 59338, Korea; Yong-Gi Jeong (Manager), Center of Natural Resources Research, Jeonnam Bioindustry Foundation, 288 Woodland-gil, Anyang-myeon, Jangheung-gun, Jeollanam-do 59338, Korea.

\section{References}

Cho HD. Studies on a plan for afforestation at Tong-ri beach resort (II): analyses of crown amount and soil properties in the disaster-damage prevention forest of Pinu thunbergii PARL., the valuation on soil properties for planting and planting for afforestation. Journal of Korean Forest Society, 77: 303-314, 1988.

Choi JS, Bae HJ, Kim YC, Park NH, Kim TB, Choi YJ, Choi EY, Park SM, Choi IS. Nutritional composition and biological activities of the methanol extracts of sea mustard (Undaria pinnatifida) in market. Journal of Life Science, 18: 387-394, 2008.

Hu SJ, Kim MH, Park SK, Lee JO. Heavy metal contents in ginseng and ginseng products. Korean Journal of Food Science and Technology, 37: 329-333, 2005.

Jang SI, Kim KK, Lee BG, Kim HJ, Lew SH, Kang HC, Youn BB. A study on hair mineral concentrations in diabetic patients. Korean Journal of Family Medicine, 23: 11331140, 2002.

Jung GB, Kim MK, Lee JS, Kim WI, Kim GY, Ko BG, Kang KK, Kwon SI. Wet deposition of heavy metals during farming season in Taean, Korea. Korean Journal of Environmental Agriculture, 30: 153-159, 2011. 
Jung GB, Lee JS, Kim WI, Kin JH, Yun SG. Wet deposition of heavy metals in Suwon area. Korean Journal of Environmental Agriculture, 26: 116-123, 2007.

Kim HL, Lee IS, Kim IC. Evaluation of mineral, heavy metal and phthalate contents in mudflat solar salt and foreign salt. Korean Journal of Food Preservation, 21: 520-528, 2014a.

Kim JH, Ahn HS. Association between hair mineral and age, $\mathrm{BMI}$ and hair physical properties among Korean female adults. Asian Journal of Beauty and Cosmetology, 10: 477-485, 2012.

Kim KW, Hwang JH, Oh MJ, Kim MY, Choi MR, Park WM. Studies on the major nutritional components of commercial dried lavers (Porphyra yezoensis) cultivated in Korea. Korean Journal of Food Preservation, 21: 702709, 2014b.

Kim MG, Kim YS, Kim YS, Lee SB, Ryu KS, Yoon MH, Lee JB. A study on the content of minerals in fortified food. Journal of Food Hygiene and Safety, 29: 99-104, 2014c. Kwak YH, Bai SC, Kim DJ. Estimated availability and major minerals ( $\mathrm{Ca}, \mathrm{P}$ and $\mathrm{Mg}$ ) contents bound neutral detergent fiber (NDF) of Seaweeds. Journal of the Korean Society of Food Science and Nutrition, 39: 10731077, 2010.

Lee HS, Doe GY, Kang YH. A study on site evaluation process for thalassotherapy complex. Journal of Korean Navigation and Port Research, 43: 219-230, 2019.

Lee MK, Park JS, Lim HC, Na HS. Determination of heavy metal contents in medicinal herb. Korean Journal of Food Preservation, 15: 253-260, 2008.

Lee YM, Lee SJ, Kim SG, Hwang YS, Jeong BY, Oh KS. Food component characteristics of cultured and wild oysters Crassostrea gigas and Ostrea denselamellos in Korea. Korean Journal of Fisheries and Aquatic Sciences, 45: 586-593, 2012.

Park MS, Kim YB, Kwon KH. A study of hazardous heavy metals found in the nails of adolescents living in Seoul. Asian Journal of Beauty and Cosmetology, 12: 845-851, 2014. 


\section{국문초록}

\section{화장품용 해양치유자원의 안전성 및 품질 비교분석}

김병록, 최윤희, 이학성, 정용기

(재)전남생물산업진흥원 천연자원연구센터, 전라남도 장흥군, 한국

목적: 본 연구에서는 울진, 고성, 완도 및 태안 등 4 개 지역에서 채취한 해양치유 가능자원과 임상적용 해양치유자원을 대상으로 안 전성과 품질의 적합성을 검증하고자 수행하였다. 방법: 본 연구 소재는 해양치유 가능자원 7종(피트, 머드, 해사, 해조류, 해송, 염 지하수 및 해수)과 임상적용 해양치유자원 9종(피트, 머드, 미역, 김, 해송, 소금, 굴, 굴자숙수 및 염지하수)이었다. 채취한 해양치 유자원은 시료 전처리 후, 중금속과 유용성분(납, 비소, 카드뮴, 칼륨, 나트륨, 칼슘 및 마그네슘 등 7성분)은 유도결합플라즈마분광 분석기를 이용하여 분석하고, 특히 중금속 중 수은은 수은분석기를 이용하여 분석하였다. 결과: 중금속 분석 결과는 해양치유 가능 자원과 임상적용 해양치유자원이 모두 식품의약품안전처에서 화장품의 안전성 기준에 적합한 것으로 확인되었다. 단, 중금속 중 해 조류의 비소와 피트의 납 함량이 높은 것으로 확인되었다. 또한 품질 비교분석 결과는 각 자원별 차이는 있지만, 대조구와 유사한 수준인 것으로 확인되었다. 특히 중금속 및 유용성분 변화량은 일반적으로 함량의 변화는 없었지만, 피트의 납 함량은 증가하였고, 칼륨 함량은 감소하였다. 결론: 본 연구에서 4 개 지역 해양치유자원에 대한 중금속 및 유용성분 비교분석 결과는 대상자원 모두 안 전하고, 해양치유에 적합한 자원으로 확인되었다. 향후, 해양치유자원은 산·학·연·관의 보다 지속적이고 체계적인 연구·관리·감독 등을 통하여 해양산업 전반에 걸쳐 활용될 것으로 예상된다.

핵심어: 해양치유자원, 안전성, 중금속, 유용성분, 화장품

본 연구는 해양수산부에서 지원하는 2017년도 해양수산기술 지역특성화사업(과제번호 20170242)의 연구수행으로 인한 결과물임 을 밝힙니다.

\section{참고문헌}

곽연화, 배승철, 김대진. 해조류 $\mathrm{NDF}$ 에 결합된 주요 무기질 $(\mathrm{Ca}, \mathrm{P}, \mathrm{Mg})$ 의 함량 분석 및 추정 이용률. 한국식품영양과학 회지, 37: 1073-1077, 2010.

김기웅, 황재호, 오명주, 김민용, 최명락, 박욱민. 시판 건조김의 주요 영양성분. 한국식품저장유통학회지, 21: 702-709, 2014b.

김명길, 김영숙, 김영수, 이성봉, 유경신, 윤미혜, 이정복. 영양강화식품 중 무기질 함량 조사연구. 한국식품위생안전성학 회지, 29: 99-104, 2014c.

김지현, 안홍석. 성인여성의 모발미네랄 함량과 연령, BMI 및 모발의 물리적 특성과의 상관성. 아시안뷰티화장품학술지, 10: 477-485, 2012.

김학렬, 이인선, 김인철. 국내산 갯벌천일염과 외국산 소금의 미네랄, 중금속 및 phthalate 함량 평가. 한국식품저장유통 학회지, 21: 520-528, 2014a.

박미성, 김영배, 권기한. 서울지역 청소년 손톱에 함유된 중금속에 관한 연구. 아시안뷰티화장품학술지, $12: 845-851$, 2014.

이미경, 박정숙, 임현철, 나환식. 유통 한약재의 중금속 함량 조사. 한국식품저장유통학회지, 15: 253-260, 2008. 이영만, 이소정, 김선근, 황영숙, 정보영, 오광수. 양식산 및 자연산 굴C (rassostrea gigas, Ostrea denselamellos)의 성 분 특성. 한국수산과학회지, $45: 586-593,2012$.

이한석, 도근영, 강영훈. 해양치유단지 조성을 위한 입지평가프로세스에 관한 연구. 한국항해항만학회지, 43: 219-230. 
2019.

장수익, 김경곤, 이복기, 김형준, 유수현, 강희철, 윤방부. 당뇨 환자의 모발 내 미네랄(무기질)의 함량. 가정의학회지, 23 : 1133-1140, 2002.

정구복, 김민경, 이종식, 김원일, 김건엽, 고병구, 강기경, 권순익. 태안지역 강우의 중금속 함량 평가. 한국환경농학회지, 30: 153-159, 2011.

정구복, 이종식, 김원일, 김진호, 윤순강. 수원지역 빗물의 중금속 함량 평가. 한국환경농학회지, 26: $116-123,2007$.

조희두. 통리(桶里) 해수욕장(海水浴場) 녹지대(綠地帶) 조성(造成)에 관(關)한 연구(研究)(II). 한국임학회지, 77: 303314. 1988.

최재석, 배희정, 김양춘, 박남희, 김태봉, 최영주, 최은영, 박선미, 최인순. 시판 미역의 영양성분 및 생리활성 분석. 생명 과학회지, 18: 387-394, 2008.

허수정, 김미혜, 박성국, 이종욱. 인삼 및 인삼제품류의 중금속 함량. 한국식품과학회지, 37: 329-333, 2005. 


\section{中文摘要}

\section{作为化妆品原料的海洋修复资源的安全性以及质量比较分析}

金炳鹿，崔允姬，李學成，鄭容琦

(财) 全南生物产业振兴院天然资源研究中心，全罗南道长兴郡，韩国

目的: 由于其独特的生物学和技术特性, 海洋资源在化妆品中的潜力得到了广泛认可。在这项研究中, 我们进行 了比较分析, 以调查从韩国四个地区 (Uljin, Goseong, Wando和Taean) 收集的用于治疗和临床应用的各种 潜在海洋资源的安全性和质量。方法: 共有七种潜在的可治愈海洋资源，踠豆, 泥, 海沙, 海藻, 黑松, 盐渍 地下水和海水) 和九种可用于临床的海洋资源（即泥炭, 泥巴, 海芥末, 紫荣, 黑松, 海盐, 牡蚛, 牡蚛白开 水和盐渍地下水）。在对样品进行预处理之后, 我们使用了电感耦合等离子体发射光谱（ICP-OES）来检测, 化学分析和量化7种重金属和有用成分（铅, 砷, 镉, 钾, 钠, 钙, 此外, 还使用了永分析仪来检测和评估永的 含量, 永是美白肥㿝和面霜中常用的成分。结果: 重金属分析的结果证实, 用于治疗和临床应用的海洋资源符合 食品药品安全部化妆品的所有安全标准。因此, 它们适用于化妆品应用。然而, 发现海藻中砷和泥炭资源的铅 含量很高。此外, 尽管发现每种资源之间存在细微差异, 但该质量比较分析的结果与对照区实验相似。更具体 地, 泥炭中的铅含量增加, 而钾含量减少。结论: 在这项研究中, 对来自四个当地海洋㸝合资源的重金属和其他 有用成分进行了比较分析, 结果表明这些资源既安全又适合用于愈合应用。未来, 有望通过对产业, 大学, 研 究机构和政府政策进行更持续，系统的研究，管理和监督，在整个海洋工业中利用治䅠海洋资源。

关键词: 安全，重金属，有用成分，化妆品，海洋修复资源 